\title{
RESPONSE OF PHENOLIC METABOLISM INDUCED BY ALUMINIUM TOXICITY IN FAGOPYRUM ESCULENTUM MOENCH. PLANTS
}

\author{
O. E. SMIRNOV, A. M. KOSYAN, O. I. KOSYK, N. Yu. TARAN
}

\author{
Educational and Scientific Centre "Institute of Biology", \\ Taras Shevchenko National University of Kyiv, Ukraine; \\ e-mail:plantaphys@gmail.com
}

Buckwheat genus (Fagopyrum Mill.) is one of the aluminium tolerant taxonomic units of plants. The aim of the study was an evaluation of the aluminium $(50 \mu \mathrm{M})$ effect on phenolic accumulation in various parts of buckwheat plants (Fagopyrum esculentum Moench.). Detection of increasing of total phenolic content, changes in flavonoid and anthocyanin content and phenylalanine ammonia-lyase activity (PAL) were revealed over a period of 10 days of exposure to aluminium. The most significant effects of aluminium treatment on phenolic compounds accumulation were total phenolic content increasing (by 27.2\%) and PAL activity rising by 2.5 times observed in leaves tissues. Received data could be helpful to understand the aluminium tolerance principles and relationships of phenolic compounds to aluminium phytotoxicity.

Key words: common buckwheat, aluminium toxicity, phenolic compounds, phenylalanine ammonia-lyase, aluminium resistance.

A luminium (Al) toxicity in acid soils limits crop production all over the world. $\mathrm{Al}^{3+}$ ions are toxic to most plant species, but some plants can accumulate $\mathrm{Al}$ without showing any toxicity. Buckwheat (Fagopyrum esculentum Moench.) can accumulate $\mathrm{Al}$ in leaves and can be characterized by high $\mathrm{Al}$ resistance $[1,2] \mathrm{Al}$ resistance mechanism of primary importance is an external detoxifying of $\mathrm{Al}$ ions in rhizosphere by organic complexing agents - oxalic acid and phenolic compounds efflux [3].

There is evidence that Al toxicity can cause excessive generation and accumulation of reactive oxygen species (ROS) resulting in oxidative damages. In plant cells, the induction of ROS is one of the most important biochemical signs of Al toxicity [4]. ROS rapidly and without difficulty interact with major biomolecules, causing physiological dysfunctions [5]. The first primary link of antioxidant defence system includes high-molecular mass proteins, such as several enzymes. Superoxide dismutase (SOD, EC 1.15.1.1) is charged with removing of highly reactive superoxide anion $\left(\mathrm{O}_{2}^{-}\right)$. Catalase (CAT, EC 1.11.1.6) and peroxidase (POD, EC 1.11.1.7) are enzymes dedicated to detoxifying "relatively stable" hydrogen peroxide molecules $\left(\mathrm{H}_{2} \mathrm{O}_{2}\right)$ [6, 7].
Low-molecular mass antioxidants, like phenolic compounds, represent an aiding element of antioxidant defence system. They are of considerable interest due to their antioxidant properties in connection with their capacity to act as the protection against ROS produced in various parts of plant cells [8].

Meanwhile phenylalanine ammonia-lyase (PAL, EC 4.3.1.24) is a key enzyme in synthesis of phenolic compounds equipped in plants, which possess an antioxidant activity. Deamination of L-phenylalanine by PAL is the first step of phenylpropanoids pathway that generates phenolic compounds in plant cell. This enzyme was first discovered by Koukol and Conn in 1961 [9]. Nowadays PAL is one of the most studied plant enzymes [10]. PAL activity has been the focus of interest not only for its primary role in phenolic metabolism. Nowadays it is a matter of common knowledge that PAL activity can significantly fluctuate in response to a variety of biotic and abiotic stressors [11]. Rising of PAL activity is associated with synthesis of phenolic compounds as ROS-scavenging agents that compensate the decrease in the activity of primary antioxidant defenses - SOD, CAT and POD [7]. 
In this way, the aim of the present study was to determine changes in total phenolic, flavonoid, anthocyanin contents and the activity of PAL in various parts of buckwheat plants due to their role in aluminium resistance phenomenon.

\section{Materials and Methods}

Chemicals. The extraction solvents and reagents were of p.a. grade purity: methanol, ethanol, butyl acetate, 2-mercaptoethanol (Fisher Chemicals, New Hampshire); hydrochloric acid, trichloroacetic acid and L-phenylalanine (Sigma-Aldrich, Steinheim). Zirconyl (IV) nitrate hydrate, Folin-Ciocalteu reagent, standard cinnamic acid and quercetin 3-rutinosid (rutin) were purchased from Acros Organics (Belgium).

Plant materials. Seeds of common buckwheat (Fagopyrum esculentum Moench. cv. Rubra) were germinated in the dark at $25{ }^{\circ} \mathrm{C}$ in Petri dishes with deionized water. After 2 days, seedlings were transferred in pots with sterilized sand and half diluted Knop solution ( $\mathrm{pH}$ 6.5) in trays. On the $7^{\text {th }}$ day the $50 \mu \mathrm{M}\left(\mathrm{Al}_{2}\left(\mathrm{SO}_{4}\right)_{3} \cdot 18 \mathrm{H}_{2} \mathrm{O}\right)$ solution was supplied to half diluted Knop solution that did not contain phosphorus with full strength micronutrients. Each day the solutions with $\mathrm{Al}$ were adjusted to $4.5 \mathrm{pH}$. Experiments were conducted in controlled conditions: temperature $-25^{\circ} \mathrm{C}$, photoperiod of $16 \mathrm{~h}$ at a photosynthetic photon flux density of $\approx 200 \mu \mathrm{mol}$ photons $\mathrm{m}^{-2} \cdot \mathrm{s}^{-1}$. For investigation 17 day roots, hypocotyls and leaves of controlled and treated plants were used. All spectrophotometric assays were measured using spectrophotometer UV-1800 (Shimadzu, Japan). The results of total phenolic, flavonoid and anthocyanin contents were expressed in $\mathrm{mg} \cdot \mathrm{g}^{-1}$ of dry weight (DW).

Determination of total phenolic content. Folin-Ciocalteu reagent was used to determine total phenolic content [12]. Rutin as the dominant phenolic substance in buckwheat plants [13] was used to standard curve construction and total phenolic content calculation in the absolute methanol extracts, $25 \mathrm{mg}$ of the dried plant material was extracted with $1 \mathrm{ml}$ absolute methanol for $24 \mathrm{~h}$. Absorbance was read at $765 \mathrm{~nm}$.

Total flavonoid content determination. For flavonoid extraction, $25 \mathrm{mg}$ of the dried plant material was extracted with $1 \mathrm{ml}$ absolute methanol for $24 \mathrm{~h}$. Total flavonoid content was determined using our own method with $0.2 \%$ zirconyl (IV) nitrate hydrate $\left(\mathrm{ZrO}\left(\mathrm{NO}_{3}\right)_{2} \cdot 2 \mathrm{H}_{2} \mathrm{O}\right)$ solution and rutin as a standard, based on the work of Petry with aluminium chloride [14]. Flavonoid content was assayed by the differential spectrophotometry method, by which a solution of the sample's major component - the plant extract $(50 \mu \mathrm{l})$ was placed in the reference and sample cuvettes and the recorded spectrum represented the difference between the sample cuvette and reference cuvette. The reference cuvette contained the plant extract and $3.5 \mathrm{ml}$ of deionized water. In the sample cuvette the plant extract was added to $3 \mathrm{ml}$ deionized water and $0.5 \mathrm{ml}$ zirconyl (IV) nitrate hydrate solution. The absorbance was measured at $397.6 \mathrm{~nm}$ after 15 min at $25^{\circ} \mathrm{C}$.

Determination of anthocyanin content. Anthocyanin was extracted and estimated by the method of Beggs and Wellmann [15] with some minor modifications. Absorbance was measured at $530 \mathrm{~nm}$. Quantity of anthocyanin was calculated using cyanidin-3-glucoside coefficients - the major anthocyanin in buckwheat (molar extinction coefficient of $269001 \cdot \mathrm{cm}^{-1} \cdot \mathrm{mol}^{-1}$ and molecular weight of $\left.449.2 \mathrm{~g} \cdot \mathrm{mol}^{-1}\right)$ [16].

Phenylalanine ammonia-lyase activity assay. The PAL activity was determined by the method of Zucker [17] with some modifications. The spectrophotometric determination of PAL is based on changes of absorbance at $274 \mathrm{~nm}$ comparing with butyl acetate as blank. For enzyme analysis $0.2 \mathrm{~g}$ of plant tissues were homogenized in $4 \mathrm{ml}$ $25 \mathrm{mM}$ borate buffer ( $\mathrm{pH} \mathrm{8.8)} \mathrm{containing} 23 \mu \mathrm{l}$ of mercaptoethanol. The homogenates were centrifuged for $20 \mathrm{~min}$ at $8000 \mathrm{~g}$. The supernatant was used for enzymatic assay. The PAL assay system contained $2 \mathrm{ml}$ of the supernatant, $1 \mathrm{ml}$ of buffer, $1 \mathrm{ml}$ of $0.05 \mathrm{M}$ L-phenylalanine. The resulting mixture was heated at $37^{\circ} \mathrm{C}$ for $30 \mathrm{~min}$. The reaction was stopped by $15 \%$ trichloroacetic acid. Butyl acetate $(4 \mathrm{ml})$ was appended to the mixture tube for the reaction product (cinnamic acid) concentration. Butyl acetate (upper) fraction was used for enzymatic measuring. The results were expressed as $\mu$ moles of cinnamic acid per minute per gram of protein. Protein content were determined by the method of Bradford [18] using BSA as standard.

Statistical analysis. The results are presented as the mean \pm standard deviation $(M \pm S D)$. An analysis of the variance (ANOVA) test was used for total phenolic, flavonoids, anthocyanin contents and PAL activity quantification. Duncan's multiple range test was used to show statistical differences between the means. Differences were accepted as significant for $P \leq 0.05$. 


\section{Results and Discussion}

We observed that addition of $50 \mu \mathrm{M} \mathrm{Al}$ to the nutrient solution led to significant changes in phenolic metabolism of buckwheat plants after 10 days of exposure (Fig. 1). The total phenolic content was increased in all parts of Al treated plants compared to the control value, but the change in trends was different (Fig. 1, a). Phenolic content was increased in roots by $19 \%$ (15.16 $\left.\mathrm{mg} \cdot \mathrm{g}^{-1} \mathrm{DW}\right)$, in hypocotyls - by $15 \%$ (34.35 mg. $\mathrm{g}^{-1} \mathrm{DW}$ ). In the leaves of $\mathrm{Al}$ treated plants the total phenolic content was the highest, increased by $27.2 \%$ (72.09 $\left.\mathrm{mg} \cdot \mathrm{g}^{-1} \mathrm{DW}\right)$.

Changes of flavonoid content (Fig. 1, $b$ ) were observed in all parts of the plants under Al toxicity. The maximal influence was revealed in leaves. In these organs flavonoids content was increased by 46.11\% (41.98 mg. $\mathrm{g}^{-1} \mathrm{DW}$ ), whereas root tissues contained $4.56 \mathrm{mg} \cdot \mathrm{g}^{-1} \mathrm{DW}-73 \%$ of control value. $\mathrm{Al}$ addition did not change significantly the flavonoid content in hypocotyls of common buckwheat.

Anthocyanin content increase by $10 \%$ (1.54 mg.g ${ }^{-1} \mathrm{DW}$ ) was observed in hypocotyls and significantly decline of this index was fixed in the root system - by $64 \%$ ( $\left.0.12 \mathrm{mg} \mathrm{g}^{-1} \mathrm{DW}\right)$, meanwhile the leaves of Al treated plants contained similar levels $\left(0.87 \mathrm{mg} \cdot \mathrm{g}^{-1} \mathrm{DW}\right)$ of anthocyanins relative to the control level (Fig. 1, c).

In the same way, PAL showed different change trends of activity in variety parts of the buckwheat plants after 10 days of Al exposure (Fig. 2). Significantly higher PAL activity under Al toxicity - 2.5 times relative to the control level - was observed in leaves. The PAL activity in hypocotyls of the treated plants was raised by $43 \%$. At the same time, the PAL activity decreased by $58 \%$ in roots. Similar changes of the PAL activity in root tissues were also observed in the previous studies. In monocot sorghum $\mathrm{Al}$ caused a decrease of the PAL activity in roots [19]. The reduction of the PAL activity, observed in the root system in the presence of $\mathrm{Al}$ in buckwheat, may be the result of a retroactive inhibitory effect of accumulated phenolic compounds. Recently genetic evidence has been provided for a phenolic-depended feedback inhibition of PAL [20].

Total phenolic content increase in root tissues could be explained by lignin monomers accumulation, cell-bound POD participates in lignin monomers oxidation for lignin polymerization for cell wall strengthening [21, 22]. Al-induced deposition of lignin in the root cell walls was mainly involved
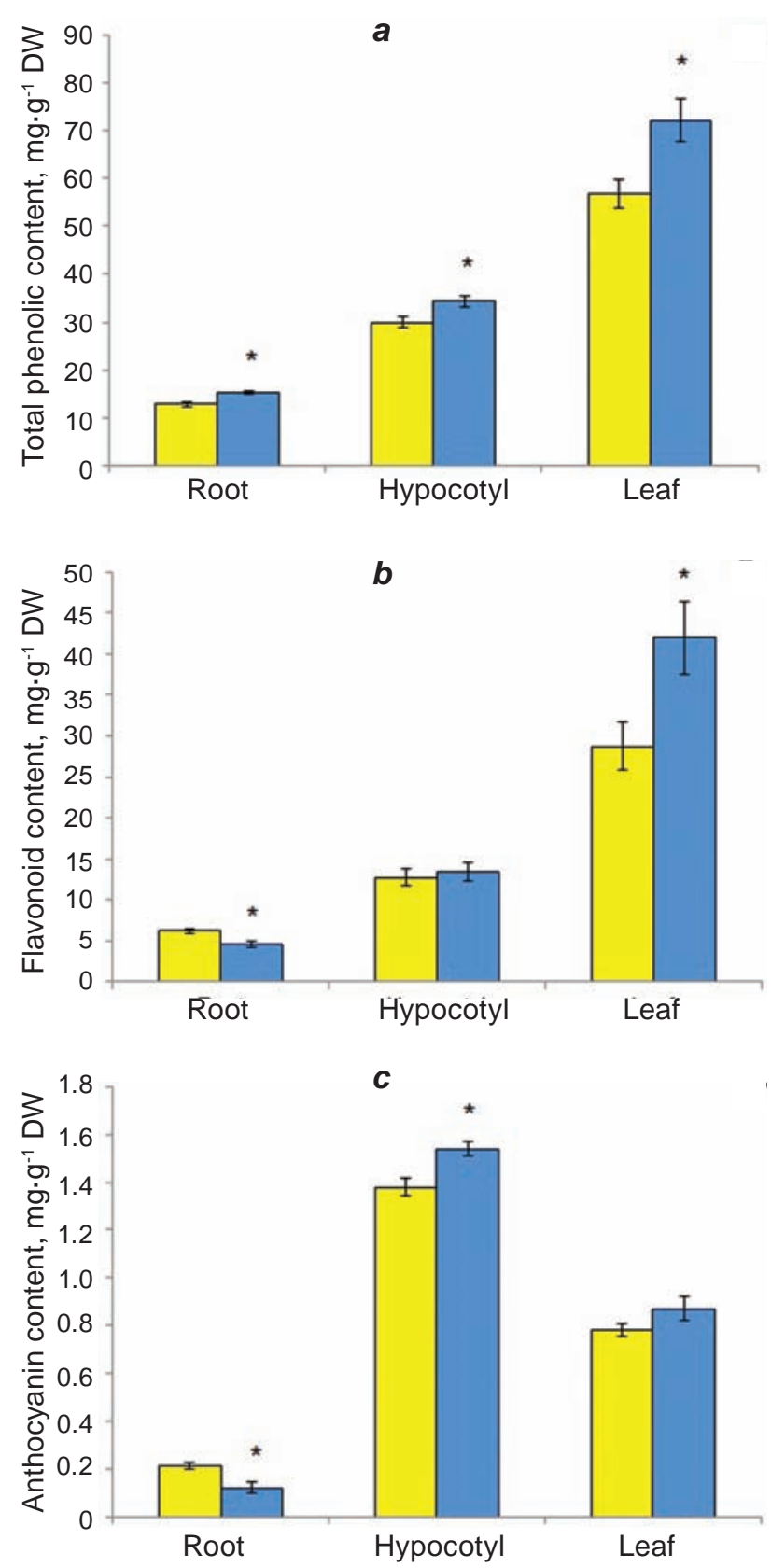

Fig. 1. Phenolic compound contents in roots, hypocotyls and leaves of common buckwheat: $\square-$ control; $\square-$ after 10 days of exposure to aluminium $(50 \mu M) ; a$ - total phenolic content, $b$ - flavonoid content, $c$-anthocyanin content; * significant at $P \leq 0.05,(M \pm S D ; n=8)$

in defence mechanisms and alleviation of oxidative damages [23]. The distal zone of root apex is the most sensitive; ROS production was detected in the root apex after two hours of $\mathrm{Al}$ exposure and increased with time exposure in pea seedlings [24]. In maize and wheat roots $\mathrm{Al}$ treatment also led to the 


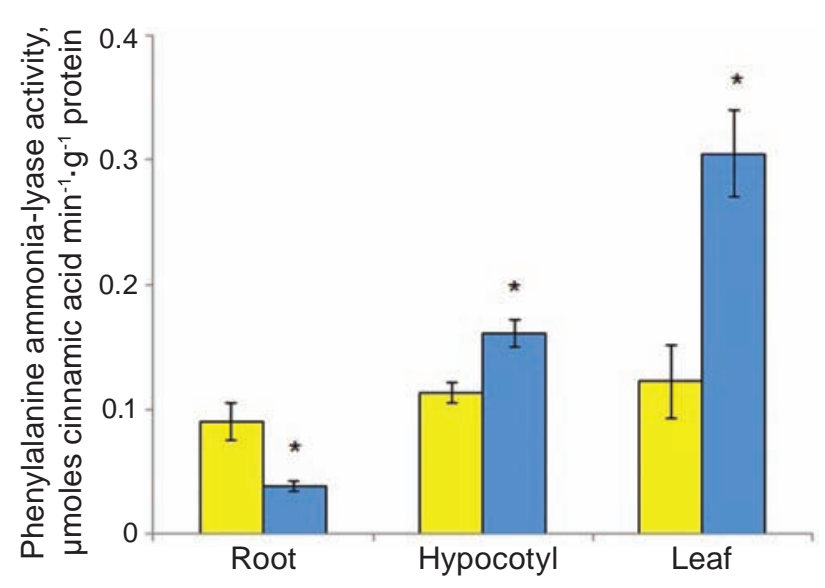

Fig. 2. Changes in PAL activity: $\square-$ control; $\square-a f-$ ter 10 days of exposure to aluminium $(50 \mu \mathrm{M})$; *significant at $P \leq 0.05,(M \pm S D ; n=8)$

increase of ROS production, SOD, CAT and POD activity [25, 26].

Phenolic compounds play several important functions in plants. They represent a striking example of metabolic plasticity enabling plants to adapt to changing biotic and abiotic environments including soil toxicity, heavy metals [27] and aluminium phytotoxicity [28]. The induction of phenolic compounds biosynthesis was observed in wheat in response to copper and nickel toxicity [29]. Phaseolus vulgaris exposed to cadmium accumulates phenolic compounds and Camellia sinensis leaves contain more phenolic compounds than control plants after exposure to solution with copper [30].

Our results suggested that $\mathrm{Al}$ addition to the nutrient solution for modelling stress conditions, led to increasing content of total phenolic compounds in various parts of treated plants, flavonoids and anthocyanins in hypocotyls and leaves. Flavonoid and anthocyanin antioxidant properties and their ability to chelate $\mathrm{Al}$ ions are related phenomena [31]. These classes of phenolic compounds can take part in reactions of ROS elimination because of their ability to donate electrons to guaiacol-type POD [32]. Moreover, phenolic compounds may be converted to prooxidants by ester hydrolysis and bioreductive metabolism during stress conditions with formation of primary oxidized products - phenoxyl radicals (Fl-O*) with a lifetime of $200 \mu$ s [33]. Fl-O^ radicals formed via oxidative processes have multiple roles in plant defence due to their ability to initiate freeradical chain reactions in the membrane and their propensity to cross-link with a variety of biomole- cules [34]. In addition, it has been shown that $\mathrm{Al}$ ions exhibit a spin-stabilizing effect on the Fl-O^ radicals [35]. The spin stabilization of Fl-O^ radicals by $\mathrm{Al}$ can be characterized by abnormal accumulations of $\mathrm{Al}$ in plant cells [32].

Meanwhile, the PAL activity was significantly increased in leaves and hypocotyls tissues and decreased in roots. The buckwheat plants ability to cope with $\mathrm{Al}$ toxicity depends on its capacity to remove ROS, which occurrence is associated with oxidative stress, by increasing synthesis and accumulation of low-molecular mass substances with high level of antioxidant properties [31]. A high content of phenolic compounds, which can form stable complexes with $\mathrm{Al}$ and take part in redox reactions, was detected in leaves $-\mathrm{Al}$ accumulating organs.

In this way, our results suggested that the increase of the PAL activity and phenolic compounds content in leaves may be related to buckwheat specific response to $\mathrm{Al}$ stress and could be proposed as a mechanism of internal aluminium detoxification closely related to preservation of ROS and/or redox homeostasis.

O. E. Smirnov designed and performed the experiments, and then wrote the first draft of the manuscript. A. M. Kosyan and O. I. Kosyk helped in biochemical assay and data statistical analysis. $\mathrm{N}$. Yu. Taran guided the research and edited the final version of the manuscript.

\section{ІНДУКОВАНА АЛЮМІНІЕВОЮ ТОКСИЧНІСТЮ ВІДПОВІДЬ ФЕНОЛЬНОГО МЕТАБОЛІЗМУ В РОСЛИНАХ FAGOPYRUM ESCULENTUM MOENCH.}

\section{О. Є. Смірнов, А. М. Косян, О. І. Косик, Н. Ю. Таран}

ННЦ «Інститут біології», Київський національний університет імені Тараса Шевченка, Україна; e-mail: plantaphys@gmail.com

Рід гречка (Fagopyrum Mill.) - один 3 алюморезистентних рослинних таксонів. Метою дослідження було з'ясувати вплив йонів алюмінію (50 мкM) на накопичення речовин фенольної природи в різних частинах рослин гречки звичайної (Fagopyrum esculentum Moench.). Показано підвищення вмісту загальної суми фенольних сполук, зміни у вмісті флавоноїдів та антоціанів та 
активності фенілаланін аміак-ліази (ФАЛ) на десяту добу експозиції рослин у присутності алюмінію. Найбільші зміни відмічено в тканинах досліджуваних листків - збільшення вмісту загальної суми фенольних сполук на $27,2 \%$ та підвищення активності ФАЛ у 2,5 раза. При цьому спостерігали інгібування активності ензиму в тканинах коренів. Одержані дані можуть бути корисними для розуміння принципів алюморезистентності гречки й участі фенольних сполук у механізмах адаптації.

К лючов і с лов а: гречка звичайна, токсичність алюмінію, фенольні сполуки, фенілаланін аміак-ліаза, алюморезистентність.

\section{ИНДУЦИРОВАНЫЙ АЛЮМИНИЕВОЙ ТОКСИЧНОСТЬЮ ОТВЕТ ФЕНОЛЬНОГО МЕТАБОЛИЗМА В РАСТЕНИЯХ FAGOPYRUM ESCULENTUM MOENCH.}

\section{А. Е. Смирнов, А. М. Косян, О. И. Косьик, Н. Ю. Таран}

\author{
УНЦ «Институт биологии», Киевский \\ национальный университет имени \\ Тараса Шевченко, Украина; \\ e-mail: plantaphys@gmail.com
}

Род гречиха (Fagopyrum Mill.) - один из алюморезистентных растительных таксонов. Целью исследования было выяснить влияние ионов алюминия (50 мкM) на накопление веществ фенольной природы в различных частях растений гречихи обыкновенной (Fagopyrum esculentum Moench.). Показано увеличение общей суммы фенольных соединений, изменение в содержании флавоноидов и антоцианов, увеличение активности фенилаланин аммиак-лиазы (ФАЛ) на десятые сутки экспозиции растений в присутствии алюминия. Наибольшие изменения отмечены в тканях исследуемых листьев - увеличение содержания суммы фенольных веществ на $27,2 \%$ и повышение активности ФАЛ в 2,5 раза. При этом наблюдали ингибирование активности энзима в тканях корней. Полученные данные могут быть полезными для понимания принципов алюморезистентности гречихи и участия фенольных соединений в механизмах адаптации.

К лю че вы е с лов в: гречиха обыкновенная, токсичность алюминия, фенольные соединения, фенилаланин аммиак-лиаза, алюморезистентность.

\section{References}

1. Ma J. F., Hiradate S., Matsumoto H. High aluminum resistance in buckwheat. II. oxalic acid detoxifies aluminum internally. Plant Physiol. 1998; 117(3): 753-759.

2. Shen R., Ma J. F. Distribution and mobility of aluminium in an Al-accumulating plant, Fagopyrum esculentum Moench. J. Exp. Bot. 2001;52(361): 1683-1687.

3. Ma J. F. Role of organic acids in detoxification of aluminum in higher plants. Plant Cell Physiol. 2000; 41(4): 383-390.

4. Yamamoto Y., Kobayashi Y., Devi S. R., Rikiishi S., Matsumoto H. Aluminum toxicity is associated with mitochondrial dysfunction and the production of reactive oxygen species in plant cells. Plant Physiol. 2002; 128(1): 63-72.

5. Choudhury S., Panda P., Sahoo L., Panda S. K. Reactive oxygen species signaling in plants under abiotic stress. Plant Signal Behav. 2013; 8(4): e23681.

6. Fan Q. J., Liu J. H. Nitric oxide is involved in dehydration/drought tolerance in Poncirus trifoliata seedlings through regulation of antioxidant systems and stomatal response. Plant Cell Rep. 2012; 31(1): 145-154.

7. Ferdinando M., Brunetti C., Fini A., Tattini M. Flavonoids as antioxidants in plants under abiotic stresses. In: Ahmad P., Prasad M.N.V. (eds) Abiotic Stress Responses in Plants: metabolism, productivity and sustainability. Springer Science+Business Media, LLC, New York, 2012; P. 159-179.

8. Apel K., Hirt H. Reactive oxygen species: metabolism, oxidative stress, and signal transduction. Annu. Rev. Plant Biol. 2004; 55: 373-399.

9. Koukol J., Conn E. The metabolism of aromatic phenylalanine deaminase of Hordeum vulgare. J. Biol. Chem. 1961; 236: 2692-2698. 
10. Boudet A. M. Evolution and current status of research in phenolic compounds. Phytochem. 2007; 68(22-24): 2722-2735.

11. Dixon R. A., Paiva N. L. Stress-induced phenylpropanoid metabolism. Plant Cell. 1995; 7(7): 1085-1097.

12. Bobo-García G., Davidov-Pardo G., Arroqui C., Vírseda P., Marín-Arroyo M. R., Navarro M. Intra-laboratory validation of microplate methods for total phenolic content and antioxidant activity on polyphenolic extracts, and comparison with conventional spectrophotometric methods. J. Sci. Food Agric. 2015; 95(1): 204-209.

13. Li X., Kim J. K., Park S. Y., Zhao S., Kim Y. B., Lee S., Park S. U. Comparative analysis of flavonoids and polar metabolite profiling of Tanno-original and Tanno-high rutin buckwheat. J. Agric. Food Chem. 2014; 62(12): 2701-8.

14. Petry R. D., Ortega G. G., Silva W. B. Flavonoid content assay: influence of the reagent concentration and reaction time on the spectrophotometric behavior of the aluminium chloride-flavonoid complex. Pharmazie. 2011; 56(6): 465-70.

15. Jaleel C. A., Wang G., Ahmad P. Changes in the photosynthetic characteristics of Catharanthus roseus L. as a result of exogenous growth regulators. Plant Omics J. 2009; 2(4): 169-174.

16. Giusti M. M., Wrolstad R. E. Unit F1.2: anthocyanins. Characterization and measurement with UV-visible spectroscopy. In: Wrolstad R. E. (ed) Current protocols in food analytical chemistry. John Wiley \& Sons, New York, 2001; P. F1.2.1-1.2.13.

17. Zucker M. Induction of phenylalanine deaminase by light and its relation to chlorogenic acid synthesis in potato tuber tissue. Plant Physiol. 1965; 40(5): 779-784.

18. Bradford M. M. A rapid and sensitive method for the quantitation of microgram quantities of protein utilizing the principle of protein-dye binding. Anal. Biochem. 1976; 72: 248-254.

19. Pereira P., Cambraia J., Sant'Anna R., Mosquim P. R., Moreira M. A. Aluminium effects on lipid peroxidation and the activities of enzymes of oxidative metabolism in sorghum. Rev. Bras. Plant Nutr. 1999; 43: 1009-1014.

20. Yin R., Messner B., Faus-Kessler T., Hoffmann T., Schwab W., Hajirezaei M. R., von Saint Paul V., Heller W., Schäffner A. R. Feedback inhibition of the general phenylpropanoid and flavonol biosynthetic pathways upon a compromised flavonol-3-O-glycosylation. J. Exp. Bot. 2012; 63(7): 2465-2478.

21. Kilpelainen I., Teeri T. H., Simola L. K. Lignification related enzymes in Picea abies suspension cultures. Physiol. Plant. 2002; 114(3): 343-353.

22. Michalak A. Phenolic compounds and their antioxidant activity in plants growing under heavy metal stress. Polish J. Environ. Stud. 2006; 15(4): 523-530.

23. Hossain M. A., Zakir Hossain A. K. M., Kihara T., Koyama H., Hara T. Aluminum-induced lipid peroxidation and lignin deposition are associated with an increase in $\mathrm{H}_{2} \mathrm{O}_{2}$ generation in wheat seedlings. Soil Sci. Plant Nutr. 2005; 51(2): 223230.

24. Sujkowska-Rybkowska M., Borucki W. Localization of hydrogen peroxide accumulation and diamine oxidase activity in pea root nodules under aluminum stress. Micron. 2014; 57: 13-22.

25. Boscolo P. R. S., Menossib M., Jorgea R. A. Aluminum-induced oxidative stress in maize. Phytochem. 2003; 62(2): 181-189.

26. Babourina O., Ozturk L., Cakmak I., Rengel Z. Reactive oxygen species production in wheat roots is not linked with changes in $\mathrm{H}^{+}$fluxes during acidic and aluminium stresses. Plant Signal Behav. 2006; 1(2): 71-76.

27. Schützendübel A., Polle A. Plant responses to abiotic stresses: heavy metal-induced oxidative stress and protection by mycorrhization. J. Exp. Bot. 2002; 53(372): 1351-1365.

28. Winkel-Shirley B. Biosynthesis of flavonoids and effects of stress. Curr. Opin. Plant Biol. 2002; 5(3): 218-223.

29. Diaz J., Bernal A., Pomar F., Merino F. Induction of shikimate dehydrogenase and peroxidase in pepper (Capsicum annuum L.) seedlings in response to copper stress and its relation to lignification. Plant Sci. 2001; 161: 179-188.

30. Saha D., Mandal S., Saha A. Copper induced oxidative stress in tea (Camellia sinensis) leaves. J. Environ. Biol. 2012; 33(5): 861-866.

31. Procházková D., Boušová I., Wilhelmová N. Antioxidant and prooxidant properties of flavonoids. Fitoterapia. 2011; 82(4): 513-523.

32. Sakihama Y., Cohen M. F., Grace S. C., Yamasaki H. Plant phenolic antioxidant and prooxidant activities: phenolic-induced oxidative damage mediated by metals in plants. Toxicology. 2002; 177(1): 67-80. 
33. Bayrakçeken F., Aktas S., Toptan M., Unlugedik A. High resolution electronic absorption spectra of anisole and phenoxyl radical. Spectrochim Acta. 2003; 59(1): 135-138.

34. Cohen M. F., Sakihama Y., Yamasaki H. Roles of plant flavonoids in interactions with microbes: from protection against pathogens to the mediation of mutualism. In: Pandalai S. G. (ed.) Recent Research Developments in Plant Physiology 2. Research Signpost, Trivandrum, 2001; P. 157-173.

35. Kalyanaraman B. Characterization of o-semiquinone radicals in biological systems. Methods Enzymol. 1990; 186: 333-343.

Received 23.06.2015 